\title{
"As it is said in a Sutra": Freedom and Variation in Quotations from the Buddhist Scriptures in Early Bka'-gdams-pa literature
}

\author{
Ulrike Roesler \\ Oriental Institute, University of Oxford
}

\begin{abstract}
The phyi dar or "later spread" of Buddhism in Tibet is known to be a crucial formative period of Tibetan Buddhism; yet, many questions still wait to be answered: How did Tibetan Buddhist teachers of this time approach the Buddhist scriptures? Did they quote from books or from memory? Did they study Buddhism through original Sūtras or exegetical literature? To what degree was the text of the scriptures fixed and standardised before the Bka' 'gyur and the Bstan 'gyur were compiled?

In search for some answers to questions such as these, the present article focuses on the gzhung pa or "scriptural tradition" of the Bka'-gdams-pa school of Tibetan Buddhism. Their works contain quotations from the Indian Buddhist scriptures that sometimes differ markedly from the mainstream editions of the Bka' 'gyur and Bstan 'gyur. There are several possible reasons for such discrepancies: The Tibetan authors might be quoting a different Tibetan translation that was later discarded by the redactors of the Tibetan canon; they might be quoting from a secondary source such as a commentary or Buddhist anthology; or they might be quoting from memory, changing the text either deliberately or by accident. Giving examples from works of the early Bka'gdams-pa masters this article discusses how textual deviations from the canonical versions can be explained. It will thereby give some insights into the way the Indian Buddhist scriptures were studied and transmitted in the Tibetan Buddhist tradition around the $11^{\text {th }}-13^{\text {th }}$ centuries.
\end{abstract}

Keywords: Tibetan Buddhism; Buddhist canonical scriptures; Tibetan translation; Bka'gdams-pa, textual reuse 


\section{Introduction}

Tibetan Studies has made good progress in tracing the steps taken in the enormous project of translating the Indian Buddhist scriptures into Tibetan that began in the $7^{\text {th }}$ and $8^{\text {th }}$ centuries and after various stages of selection and redaction, led to the large canonical mainstream editions of the Bka' 'gyur ('word of the Buddha' in its Tibetan translation) and Bstan 'gyur (works by Indian authors in their Tibetan translation). The early imperial catalogues, the colophons of the individual translations themselves, Tibetan historio-

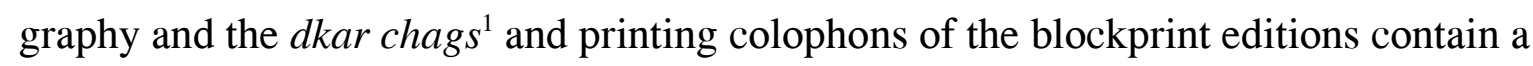
fair amount of information on this process. ${ }^{2}$ Similarly, we have plenty of sources giving insight into the way the Buddhist scriptures were (and continue to be) studied in the large monastic institutions that dominated the intellectual scenery of Buddhist education over the last four or five centuries.

However, there are still many gaps in our understanding of the reception of the Buddhist scriptures in Tibet. In particular, there seems to be a lack of resources for the period stretching from the collapse of the Tibetan empire (mid- $9^{\text {th }}$ century) into the early phyi dar ('later dissemination' of Buddhism, starting in the late $10^{\text {th }} /$ early $11^{\text {th }}$ centuries). This lack of a coherent documentation is mainly due to political and economic factors: During this period, there was no central state patronage for Buddhism and therefore no centralised mechanisms of record keeping. At the same time, the large and powerful monastic institutions had not emerged yet, and thus there was no well-established monastic system of documentation either.

This is regrettable since the phyi dar is highly interesting: It is not just a 'renaissance' of a pre-existing Buddhist culture, but rather a vibrant formative period full of literary and intellectual experiments and innovations. The process of translation, reception and transmission of the Indian Buddhist scriptures was still in flux, the canonical collections of the Bka' 'gyur and Bstan 'gyur were still in the making and no mainstream editions of the authoritative texts were available. At the same time, Tibetan chos 'byung ('histories of Buddhism') and biographies of Buddhist masters record a rapid growth of the Buddhist communities around the late $11^{\text {th }}$ and the $12^{\text {th }}$ centuries, and they also report that individual teachers taught and transmitted specific scriptures and practices that became the nucleus of their respective traditions. One may wonder how this decentralised process of intellectual engagement with and appropriation of Buddhism may have worked on a practical level, or, if we focus specifically on the reception of

1 Dkar chag means 'register, inventory, catalogue'. In the context of text collections it usually designates a table of contents, but a dkar chag can also be much more elaborate, like for instance the two final volumes of the Derge blockprint edition of the canon, also known as its dkar chag, that include an account of the history of Buddhism in general and the production of the blockprint edition itself.

2 For an excellent recent survey see Scherrer-Schaub 2009 (on Tibet in particular see pp. 161-167). 
Buddhist literature: To what extent would an average Tibetan monk of this period have been familiar with the Buddhist scriptures, and what kind of resources did he have at hand?

A related, but slightly different question is how the Tibetan Buddhists of the phyi dar approached the "word of the Buddha". Which works or textbooks were used in order to teach and study Buddhism? It is well-known that, for instance, in the curriculum of the big Dge-lugs-pa institutions, Indian Buddhist scriptures are largely studied through the Indian and Tibetan exegetical literature. The word of the Buddha is thus viewed through the lens of commentaries and sub-commentaries, and the right understanding of the $b k a$, the "word of the Buddha", is safeguarded through the tradition of exegesis rather than through the immediate study of the scriptures themselves. ${ }^{3}$ Scholars have found evidence of this tendency already in the writings of Tsong-kha-pa, who, for instance in his Lam rim chen mo, is often quoting from secondary sources rather than the original Sūtras. ${ }^{4}$

The situation seems to have been rather different during the early translation period. The imperial catalogues of works translated, the Ldan dkar ma (or Lhan dkar ma) and the 'Phang thang $m a,{ }^{5}$ demonstrate that priority was given to the word of the Buddha itself. Mahāyānasūtras are among the earliest works translated ${ }^{6}$ and make up a large proportion of the translations from the time of the Tibetan empire. From the $10^{\text {th }} / 11^{\text {th }}$ centuries on, in the gsar ma period, we observe a shift towards śāstra that seems to mirror a stronger interest in the exegetical tradition, and we may thus presume that this might reflect the beginning of an approach through the medium of commentaries.

In order to understand these developments in more detail, it is worth having a closer look at the indigenous Tibetan literature from the time of the phyi dar, around the $11^{\text {th }}$ to $13^{\text {th }}$ centuries, before the translated scriptures were compiled into the $B \mathrm{ka}$ ' 'gyur and Bstan 'gyur. This may enable us to get a better idea of this important formative

\footnotetext{
3 Dreyfus 2003 provides an intriguing and very accessible description of the education system in Dgelugs-pa monasteries.

4 Langelaar has analysed the quotations in Tsong-kha-pa's Lam rim chen mo and comes to the conclusion that the majority are secondary quotations, mainly from Śāntideva's Śikșāsamuccaya and Gro-lungpa's Bstan rim chen mo. On a slightly different note, Wedemeyer 2006 argues that Tsong-kha-pa's scholarship is based on the Tibetan tradition rather than Sanskrit originals of the Buddhist scriptures. In his study of the Rim lnga gsal sgron he demonstrates that Tsong-kha-pa's discussion of different Tibetan translations is not based on 'philological' criteria (i.e., which Tibetan translation renders the Sanskrit original most accurately), but rather on their exegetical value (i.e., which Tibetan translation makes the best sense within Tsong-kha-pa's own exegetical framework).

5 The Ldan dkar ma catalogue was published by Lalou 1953. For a detailed analysis of the 'Phang thang ma catalogue see Halkias 2004.

6 According to the introduction of the Sgra sbyor bam po gnyis pa, the Lankāuatārasūtra and the Ratnameghasūtra belong to the earliest layer of Tibetan translations of the Indian Buddhist scriptures and their translation style set the standard for the rules laid down in the Sgra sbyor itself, see Sgra sbyor ed. 1990: 4. For a detailed discussion see Scherrer-Schaub 2002: 292-304.
} 
period when Tibetan monk scholars were just beginning to create their own inner-Tibetan exegetical traditions.

In the present article I focus on sources from the first three generations of the Bka'gdams-pa tradition, and in particular on a tradition that became known as the gzhung pa, 'the scriptural tradition', ${ }^{7}$ since a tradition that designates itself as 'based on the scriptures' seems a good starting point for understanding the reception of Buddhist literature.

The Bka'-gdams-pa tradition as a whole traces itself back to Atiśa Dīpamkaraśrījñāna (982-1054), a scholar from Bengal who was invited by the kings of Western Tibet and spent the last twelve years of his life traveling and teaching in Western and Central Tibet. Amongst his influential Tibetan disciples, the layman 'Brom-ston Rgyalba' $i$ 'byung-gnas (1005-1064) is regarded as the founding father of the Bka'-gdams-pa. His three main pupils who studied with him at Rwa-sgreng monastery became known as the sku mched gsum, the 'three [spiritual] brothers'. The lineage of the gzhung pa goes back to one of them: to Po-to-ba Rin-chen-gsal (1027/31-1105) and his students.

\section{Scriptural quotations in Po-to-ba's Dpe chos ('Dharma Exemplified')}

In order to see how the 'scriptural tradition' (gzhung pa) approached Buddhist literature I will examine works that were composed by their early teachers, focusing on their quotations from the Indian Buddhist scriptures. These quotations are important witnesses that show us which texts the authors had access to, and in what form. My examples will be drawn from a work called the Dpe chos rin chen spungs pa, 'The Buddhist Doctrine Exemplified, [like] Piled up Jewels', that contains Po-to-ba's instructions on the 'graded path' to awakening (lam rim). Po-to-ba has become famous in Tibet for his original and humorous way of explaining the Buddhist doctrine and in particular for his use of examples, parables and anecdotes which is mirrored in works from his tradition. His Dpe chos skilfully combines Indian scriptural material with indigenous Tibetan similes and proverbs to make the Buddhist dharma accessible and appealing to his Tibetan audience.

It is important to note that in the $11^{\text {th }}$ century we are still in a largely oral environment, or rather, in a period of transition from mostly oral teachings to a large

7 In particular, this tradition regards six texts as their main sources, the so-called gzhung drug: the Jātaka (in the Tibetan tradition particularly referring to the Jātakamālā of Āryaśūra) and Udānavarga, said to teach right faith, Śāntideva's Śikșāsamuccaya and Bodhi(sattva)caryāvatāra, said to teach the right view, and Asañga's Mahāyānasūtrālaṃkāra and Bodhisattvabhūmi, said to teach right practice. 
scale production of written works. ${ }^{8}$ In this period, works were often written down by the students of important masters based on their instructions. This is also true of the Dpe chos which was not composed by Po-to-ba himself, but by his disciples who recorded his instructions from memory after he had passed away in 1105. These students, Grab-pa and Brag-dkar-pa, composed a short and a long version of the work respectively, and based on these Lce-sgom Shes-rab rdo-rje (1124/25-1204/05) ${ }^{9}$ compiled a middle-length version that seems to be the only one that has survived. Blockprint editions of this version comprise between 170 and 251 folios. ${ }^{10}$

The Dpe chos has a sister compendium, the Be'u bum sngon po, written by another disciple of Po-to-ba, Dol-pa Shes-rab rgya-mtsho (1059-1131), who heard about the compilation of the Dpe chos and thereupon decided to publish his own record of Po-toba's instructions. ${ }^{11}$ These works from Po-to-ba's tradition can be compared with related literature on the 'graded path' from the same period, such as the famous Bstan rim chen mo by Gro-lung-pa ( $11^{\text {th }}-12^{\text {th }}$ cent.) and the Thar pa'i rgyan by Sgam-po-pa (10791153). ${ }^{12}$ All these works were written around the beginning of the $12^{\text {th }}$ century and contain instructions on the graded path to awakening that go back to the Indian scholar Atiśa. ${ }^{13}$ Thus, they represent a common tradition and may serve as a solid basis for assessing the scriptural scholarship in these circles. They in turn have had a long-lasting impact on Tibetan 'graded path' literature, since they became important resources for Tsong-kha-pa when he composed his works on the graded path and have thus had a tremendous impact on the ensuing scholastic tradition of the lam rim.

The Dpe chos contains citations from 63 Indian Buddhist works. Out of these, 40 belong to category of $b k a$ ' (the 'word of the Buddha' later assembled in the Bka' 'gyur), and 23 belong to the category of bstan bcos (Indian scholastic works later forming the

\footnotetext{
8 The oral character is mirrored in the works of this period that contain numerous idiomatic expressions of the spoken language and the dialect (yul skad) of their home region. Moreover, the oral 'sayings' or 'pithy statements' of the early Bka'-gdams-pa teachers were recorded by their students and have survived in anthologies such as the Bka' gdams gsung bgros thor bu of Lce-sgom Shes-rab rdo-rje and in parts of the Bka' gdams glegs bam. Orality is thus still very discernible even in the written legacy of the tradition.

9 On him see Sørensen 1999. The dating is taken from van der Kuijp 2001: 69.

${ }^{10}$ I have consulted four blockprint and two manuscript editions of the work. For a detailed description of the textual witnesses see Roesler 2011, chapter 7.

${ }^{11}$ It consists of a metrical root text by Dol-pa Rin-po-che himself and a commentary by his disciple Lha 'Bri-sgang-pa. An English translation of the root text by the present author is due to be published by Wisdom Publications in the "Library of Tibetan Classics" series.

12 See Jackson 1996 for a survey of lam rim and bstan rim literature of this period. For further comparisons and a discussion of the structure of these works see Roesler 2011: 37-47.

${ }^{13}$ The classification of "three kinds of individuals" in his Bodhipathapradipa became foundational for the Tibetan lam rim. In addition to this seminal treatise, the collection Jo bo'i chos chung contains other short works ascribed to Atiśa that outline the stages of the path to enlightenment, see Roesler 2011: 45-47.
} 
Bstan 'gyur). Thus we have a clear predominance of the Sūtras over śāstra literature. ${ }^{14}$ However, certain works of the śāstra type are highly important too; in particular Śantideva's Bodhicaryāvatāra which is the most frequently cited work in the Dpe chos (40 quotations). It is followed by the Ratnagunasamcayaga $\bar{t} t h \bar{a}$ with 21 quotations. Then, there are a number of quotations from (in descending order): the Prajñāpāramitā (16), the Mahāyānasutrālaṃkāra (12), Nāgārjuna's Suhṛllekha (10) and Ratnāvalī (8), the Lalitavistara (7), and a few from the Gạ̣davyūha (4) and the Kāsyapaparivarta (4). Most other works are quoted only once or twice.

One may wonder in what form these Indian scriptures were accessible to Po-to-ba himself and to his disciples who wrote the Dpe chos. What kind of manuscript collections did they have access to? We need to keep in mind that there was no 'canon' yet and that scholars presumably based their instructions on individual texts they had studied and that were considered important within their tradition rather than on the notion of a (more or less) fixed set of Buddhist scriptures. Furthermore, the early Bka'-gdams-pa monasteries were fairly small and newly founded institutions ${ }^{15}$ and would not have had enormous libraries. Moreover, we know from Tibetan biographies that the Buddhist masters used to travel a lot, and presumably would not have carried large manuscript collections with them. Thus, the number of manuscripts a scholar had access to must have been limited. In addition, keeping in mind the strongly oral component of the scholarship of the time, we may also wonder whether Buddhism was mostly studied through manuscripts, or whether teaching and studying the scriptures was largely an oral activity.

3. Deviations in quotations from the scriptures

A close reading of the works of the early Bka'-gdams-pa masters can give some insight into the way they approached the scriptures. In particular, the discrepancies between scriptural quotations in early Bka'-gdams-pa works such as the Dpe chos and the later mainstream editions of the Tibetan canon deserve attention, since they reveal something about the way the scriptures were studied and transmitted. Leaving corruptions due to an inaccurate written transmission aside, such variations could in theory be due to several causes:

1. The Dpe chos could preserve traces of an early translation that was not included in the canon, or a canonical translation before its revision. Thus, it might give us a

${ }^{14}$ Interestingly, the Dpe chos does contain a collective term for the Buddhist scriptures: bka' bstan bcos. On this expression as a designation for the "canon avant la lettre" see Skilling 1997. The Dpe chos moreover designates the canonical scriptures as bka' sde snod, the 'baskets of the word [of the Buddha]'.

${ }^{15}$ For a brief survey see Tshul-khrims 2001 and Roesler \& Roesler 2004. 
glimpse of lost versions of the canonical scriptures and would be highly interesting for philological studies of the respective works.

2. Secondly, it is also possible that the quotations are simply inaccurate, possibly because the authors were quoting from memory rather than from written texts. This would tell us something about the way the works were memorised and used in oral instructions.

3. Thirdly, it could also be that we are dealing with secondary quotations taken from other sources such as exegetical literature or compendia. That would indicate that already here, scholars were working with digests of the Buddhist scriptures (samuccayas) or with exegetical literature rather than the original primary sources.

If we could find arguments supporting one or the other of these alternatives, we would learn a lot about Buddhist scholarship and textual studies in the early Bka'-gdams-pa circles, and arguably about Buddhist scholarship of the early phyi dar period in general. A comparison of the quotations in the Dpe chos with the canonical versions shows that they do indeed give us certain clues. We can discern different types of deviations in the Dpe chos that seem to point to the fact that actually all three of the possibilities mentioned do occur in the text, as I shall try to demonstrate with some examples.

\subsection{Evidence for earlier translations?}

In a few cases the Dpe chos seems to refer to earlier translations (or earlier versions of translations) of canonical works or uses archaic work titles that came out of use later. For example, it quotes the Gandavyūha under the Tibetan title Sdong po bkod $p a$, while the later mainstream editions of the Bka' 'gyur call it Sdong po brgyan pa. The title Sdong po bkod pa is also attested in sources from the time of the Tibetan empire (the Mahāvyutpatti and the Lhan dkar ma catalogue) and thus seems more archaic. The same title is also attested in the Ta-bo inscriptions, and it is used in Atiśa's Bodhipathapradipapañjikā, his Mahāsūtrasamuccaya and in Gro-lung-pa's Bstan rim chen mo, which indicates that the $11^{\text {th }}$ and $12^{\text {th }}$ century Bka'-gdams-pa circles knew it under this name. ${ }^{16}$

Apart from that, there seem to be rare, but significant cases in which the Dpe chos is quoting a translation that is different from the one in the mainstream editions of the Bka' 'gyur and Bstan 'gyur. A case in point are two stanzas from Candrakīrti's Madhyamakāvatāra. The Dpe chos does not mention this work by name, but the stanzas can clearly be identified as quotations from the second and the sixth chapter of this work. However, both stanzas look different from the well-known canonical translation by

${ }^{16}$ The title Sdong po bkod pa appears in Dpe chos no. 15.13+ and 21.18- (see Roesler 2011). For a discussion of the title in the Ta-bo inscriptions and in other sources see Steinkellner 1995: 16-18. 
Tilaka(kalaśa) and Pa-tshab Nyi-ma-grags (*1055). The first stanza is from the chapter on síla and runs:

\section{Madhyamakāvatāra 2,5}

"If someone is in control and lives in a favourable situation

and, under these circumstances, does not seize on this, ${ }^{17}$

who will then later draw him out

when he has fallen into the abyss and has come under the control of others?"

The translation by Tilakakalaśa and Pa-tshab Nyi-ma-grags runs: ${ }^{18}$

gang tshe rang dbang 'jug cing mthun gnas pa $\mid$

gal te 'di bdag 'dzin par mi byed na ||

g.yang sar lhung bas gzhan dbang 'jug 'gyur ba ||

de las phyi nas gang gis slong bar'gyur||

However, there was another, slightly earlier translation of the work by Kṛ̣napāda and Nag-tsho lo-tsa-ba (1011-64), which was later revised by the same Pa-tshab Nyi-magrags who also translated the work himself. ${ }^{19}$ Its $k \bar{a} r i k \bar{a}$ s (but not the commentary) have been preserved in Q, and Red-mda'-ba's commentary Dbu ma la 'jug pa'i rnam bshad de kho na nyid gsal ba'i sgron ma quotes this translation and can therefore be used as a second witness. ${ }^{20}$

In Nag-tsho's translation, the stanza runs: ${ }^{21}$

rang dbang 'jug cing mthun pa'i yul gnas pa ||

de tshe 'di dag 'dzin par mi byed na ||

g.yang sar lhung bas gzhan dbang 'jug 'gyur ba ||

de tshe de nas gang gis 'byin par'gyur|

Line b, dag : bdag in Red-mda'-ba's commentary

${ }^{17}$ Bdag needs to be understood separately from 'dzin, thus not bdag 'dzin in the sense of "clinging to the ego", but "seizing (this, 'di) oneself".

${ }^{18}$ D no. 3861, mdo 'grel 'a, fol. 202b, Q no. 5262, p. 100,4 = dbu ma 'a, fol. $246 a$.

19 Tauscher (1981: 11) addresses the issue of the close resemblence between Pa-tshab's own translation and his revision of Nag-tsho's translation: „[Nag-tsho's] Übersetzung der Madhyamakāvatārakārikā ist vom Übersetzerteam des Bhāṣyam korrigiert, was vermuten läßt, daß sie dadurch etwas von ihrer Eigenständigkeit eingebüßt hat. Tatsächlich underscheidet sie sich - wenigstens in dem von mir bearbeiteten Textabschnitt im wesentlichen nur formal von jener des Pa tshab. "This observation raises the question how far $Q$ really represents a truly separate translation.

${ }^{20}$ See Tauscher 1981 and 1989.

${ }^{21}$ Q no. 5261, p. 93,1 = dbu ma 'a, fol. 227a. 
Interestingly, the stanza in the Dpe chos (no. 19.9+ in Roesler 2011) is partly similar to Nag-tsho's, and I have marked words they share against Pa-tshab's translation in grey:

\author{
rang dbang yod cing mnyam par gnas pa'i tshe || \\ de tshe bdag nyid 'dzin par mi byed na $\mid$ \\ gzhan dbang song zhing ngan 'gror lhung gyur pa $\mid$ \\ de tshe de nas su zhig 'byin par'gyur || \\ Line b, de tshe : gal te in the Urga blockprint of the Dpe chos
}

The stanzas in the Dpe chos and in the revised version of Nag-tsho's translation have certain features in common. At the same time, Pa-tshab's translation and his revised version of Nag-tsho's translation agree to a large extent too. It is highly tempting to hypothesise that the Dpe chos represents the original translation by Nag-tsho lo-tsa-ba, and that Pa-tshab when he revised Nag-tsho's translation retained part of it, but changed some details and thus made it more similar to his own translation of the work. Be this as it may, the Dpe chos seems to be a witness representing some version of Nag-stho's unrevised translation which is not preserved otherwise, and as such deserves our attention.

The second quotation from the Madhyamakāvatāra gives us a chance to crosscheck the evidence. It is the famous final stanza of chapter 6 about the bodhisattva who, like a "king of geese", reaches the qualities of Buddhahood, carried by the wings of conventional and absolute truth:

\title{
Madhyamakāvatāra 6,226
}

"Spreading the broad white wings of conventional and absolute truth,

this king of geese is placed ahead by the [other] geese, the beings, and through the power of the wind of good deeds

he goes to the other shore of the ocean of the virtues of the Victorious ones."

The canonical translation by Tilaka(kalaśa) and Pa-tshab Nyi-ma-grags runs: ${ }^{22}$

kun rdzob de nyid gshog yangs dkar po rgyas gyur pa $\mid$

ngang pa'i rgyal po de ni skye bo'i ngang pa yis ||

mdun du bdar nas dge ba'i rlung gi shugs stobs kyis ||

rgyal ba'i yon tan rgya mtsho'i pha rol mchog tu 'gro ||

\footnotetext{
${ }^{22}$ D no. 3861, $m$ do 'grel 'a, fol. $215 a$; Q no. 5262, p. 106,2 = dbu ma 'a, fol. 260 a.
} 
The translation by Kṛ̣napāda and Nag-tsho lo-tsa-ba in its canonical version, ${ }^{23}$ that is to say, after the revision by Pa-tshab lo-tsa-ba, is almost identical with Pa-tshab's own translation. The differences between them are marked in grey (the second is only an insignificant orthographical variant):

kun rdzob don dam gshog yangs dkar po rgyas gyur pa ||

ngang pa'i rgyal po de ni skye bo'i ngang pa yis ||

mdun du brdar nas dge ba'i rlung gi shugs stobs kyis ||

rgyal ba'i yon tan rgya mtsho'i pha rol mchog tu 'gro ||

The Dpe chos phrases the same stanza in a very different way (no. 21.27+ in Roesler 2011):
rgyal ba yon tan rgya mtsho'i pha rol mchog tu 'gro ba gang ||
skye ba can gyi ngang pa mang po mdun bdar nas ||
bsod nams byas pa'i lam nas ngang pa'i rgyal po de ||
kun rdzob de nyid dkar po'i gshog chen brkyang nas 'gro ||

The Dpe chos quotation is irregular since the first line has thirteen syllables, whereas the stanza as a whole is written in an eleven syllable meter. All in all, the stanza conveys the same meaning, but represents an entirely different translation and even has a different order of lines. There are certainly several possibilities how this can be explained. It could be that the Dpe chos simply contains a highly inaccurate quotation from memory that renders the meaning, but not the phrasing of the original. However, in this case I would expect that at least part of the translation would be identical with the canonical one. I therefore rather assume that the Dpe chos is quoting a translation that is different from those preserved in the canon, and keeping the previous case in mind, it is very tempting to think that the Dpe chos has (more or less) retained the original translation of Nag-tsho lo-tsa-ba before its revision by Pa-tshab. If this is true, it would be an interesting witness to the earlier translation, and also to the procedure of revision: It would imply that Patshab has dramatically changed Nag-tsho's translation in this case, and that either he was so fond of this revised version that he later used it for his own translation as well, or he had already translated the work himself and revised Nag-tsho's translation on the basis of his own. If this were indeed the case, it would alert us that a revision process can have profound consequences and may go far beyond a gentle and light-handed improvement. ${ }^{24}$

${ }^{23}$ Q no. 5261, p. 98,3 = dbu ma 'a, fol. 240b.

${ }^{24}$ This would not be a singular case. Simonsson 1957 compares Central Asian fragments of translations of the Saddharmapundarika- and the Suvarnaprabhāsottamasūtra with their canonical versions and observes that the revision process has sometimes led to massive changes. 


\subsection{Quotations from memory?}

In other cases the discrepancies between the Dpe chos and the canonical versions are of a very different nature: In those passages the Dpe chos quotation corresponds word by word to the mainstream version of the canon, but every now and then it omits whole lines or changes the wording entirely. The Lalitavistara is a good example. Its canonical version was translated around the early $9^{\text {th }}$ century by a well-known team: Jinamitra, Dānaśîla, Munivarman and Ye-shes-sde. The Dpe chos contains eight quotations from this Sütra, and most of them are identical with their canonical counterparts. Thus, the compilers of the Dpe chos were clearly familiar with the Sütra in the form known from the Tibetan canon. However, in several instances the Dpe chos version differs markedly from the canonical text. I will give two examples (differences are marked in grey):

LV chapter $16(\mathrm{D}):{ }^{25}$

'dod pa dug 'dra nyes pa mtha' yas ldan $\|$ sems can dmyal dang yi dwags dud 'gror ltung $\|$ mkhas pas smad cing 'dod pa 'phags ma yin $\|$ kho bos ngar snabs rul ba bzhin du bor $\|$ 'dod pa shing gi 'bras bu bzhin du ltung $\|$ ji ltar sprin dang char pa bzhin du 'gro \| mi brtan 'gyur la ji ltar rlung bzhin 'gro $\|$ dge ba thams cad rnam par 'thor zhing slu\| de bzhin 'dod pa mi rnyed phyir yang gdung $\|$ rnyed du zin kyang chog par 'dzin mi 'gyur \| gang tshe dbang med ma rung rab gyur pa $\|$ de tshe 'dod pa sdug bsngal drag chen bskyed $\|$ rgyal po lha yi 'dod pa gang yin dang $\|$ mi yi 'dod pa bzang po gang yin pa'i $\|$ 'dod pa thams cad mi gcig gis thob kyang \| de la chog pa med de yang tshol lo $\|$ rgyal po gang dag zhi zhing dul gyur pa\| 'phags pa zag med chos kyis 'du shes gang \| shes rab mkhas pas chog pa de legs chog\| 'dod pa'i yon tan chog pa cung zad med\| rgyal po 'dod pa dag la bsten byas shing $\|$ sngon chad 'dus byas pa yi mtha' ma med $\|$ ji ltar mi dag lan tshwa'i chu 'thungs bzhin \| 'dod pa bsten na phyir zhing sred pa 'phel \|
Dpe chos (no. 5.9- in Roesler 2011):

$i d$.

sems dmyal dud 'gro yi dwags rnams su ltung \| 'dod pa 'phags min dam pa rnams kyis smad | ngar snabs btul ba bzhin du kho bos bor \| 'dod pa dug gi 'bras bu bzhin du lhung \| id.

$i d$.

$i d$.

$i d$. rnyed du zin kyang chog ni mi shes te $\|$ om.

om.

om.

om.

om. des kyang chog pa med cing da dung 'tshol \| om.

om.

om.

'dod pa'i yon tan chog pa ci yang med $\|$

om.

om.

$i d$.

'dod pa bsten na phyir yang sred pa 'phel $\|$

${ }^{25}$ D no. 0096, vol. 46, p. 237, mdo sde kha, fol. 119a. For the Sanskrit see Lalitavistara ed. Lefmann: 242 , lines $3 \mathrm{ff}$. 
While a number of lines are identical, some lines have a different word order or phrasing, and a considerable number of lines have been omitted altogether. From the general congruences we can conclude that the Dpe chos is not quoting a different translation (and in fact no other translation of the Lalitavistara is known). At the same time, the omission of complete lines while maintaining a meaningful text cannot be explained by scribal errors within a written transmission. The only plausible explanation for this type of variation is that the Bka'-gdams-pa masters are here quoting from memory, sometimes abbreviating the text by skipping whole lines, but generally conveying the basic meaning of the original. The omissions could be accidental, but it is also possible that the passage was consciously abbreviated in order to convey the essential message in a slightly condensed form for didactic purposes.

In another instance, the Dpe chos seems to quote from the Lalitavistara in an abbreviated form using a simple seven syllable meter where the canonical Tibetan translation of the Lalitavistara has thirteen syllables (I have indicated the differences and the additional syllables of the original by grey shading). Moreover, the Dpe chos quotes the lines in a different order (I have indicated this in the following quote by line numbers). Towards the end, the Dpe chos goes on in a completely idiosyncratic way that has no parallel at all in the Lalitavistara; the end is therefore not rendered here.

\section{Lalitavistara, chapter 21 (D): ${ }^{26}$}

(1) 'dod pa sdug bsngal mang po gsog cing sdug bsngal rtsa ba ste |

(2) mi mkhas rnams la bsam gtan rdzu 'phrul dka' thub nyams par byed

(3) bud med 'dod pa'i yon tan chog pa med ces mkhas pas smras ||

(4) nga ni mi mkhas rnams la shes rab chog par byed par 'gyur ||

(5) 'dod pa bsten na sred pa phyir zhing rnam par 'phel 'gyur te ||

(6) dper na mi 'ga' la la tshwa chu 'thungs par gyur pa bzhin ||

Dpe chos (no. 5.12- in Roesler 2011):

(1) 'dod pa sdug bsngal rtsa ba ste ||

(2) bsam gtan dka' thub nyams par byed ||

(6) 'dod pa la tshwa'i chu 'thungs bzhin |

(5) skom pa'i sred pa 'phel bar byed

(-) 'dod pas bud med khol por 'gyur ||$[\ldots]$

Again, the most plausible explanation is that the Dpe chos quotes from memory, rendering the basic meaning and starting in a more or less accurate (though abbreviated)

${ }^{26}$ D no. 0096, vol. 46, p. 315, mdo sde kha, fol. 158a. For the Sanskrit see Lalitavistara ed. Lefmann p. $323,21 \mathrm{ff}$. 
way, but then losing track and going on in a similar vein, but with no close resemblance to the original.

Similar examples from other works could be given, especially from the Bodhicaryāvatāra. Śantideva's work is the most frequently quoted in the Dpe chos and most quotations are very accurate. However, every now and then there are major deviations, for instance combining lines from different chapters of the work, or even inserting lines from the Sikșāsamuccaya. ${ }^{27}$ It thus seems as if the popular and well-known works are particularly prone to distortion and variation through quotations from memory - not surprisingly, since they are the ones that would usually have been committed to memory and could therefore be quoted freely, without reference to a written source. ${ }^{28}$ This applies not only to prose passages, but also to passages in verse (such as those from the Lalitavistara cited above, or the Bodhicaryāvatāra).

These examples give interesting insights into the way the Indian scriptures were studied and taught: It seems that the authors of the Dpe chos had a solid knowledge of the Buddhist classics and had committed considerable portions to memory, but citing from memory may lead to reproducing the text in a slightly deviating form, either deliberately or accidentally. It might be added that very similar techniques can be observed in contemporary settings, where Buddhist teachers often select what seems most suitable and quote from memory, adjusting passages to a given teaching context and sometimes condensing a quotation to its essential meaning.

Since the Dpe chos has been written and redacted by several hands, it is impossible to say whether it was Po-to-ba who cited the Sūtra in an abbreviated form, his disciples when they committed the Dpe chos to writing, or Lce-sgom Shes-rab rdo-rje who finally produced the middle length version of the Dpe chos that has been preserved. Be that as it may, the examples given above demonstrate that the early Bka'-gdams-pa teachers cite passages from certain well-known and popular works from memory rather than books.

\subsection{Secondary quotations?}

If the Buddhist teachers of the phyi dar were quoting scriptures from memory, this brings us to the question of how they studied and memorised them: Did they study passages from the individual original scriptures, or did they mainly know these scriptural passages from "secondary" works, in particular from anthologies of the Buddhist doctrine such as the Indian samuccayas and samgrahas? Atiśa's tradition has created a

${ }^{27}$ See Roesler 2011: 215-16.

${ }^{28}$ More examples for deviating quotations, including obvious mistakes in the Dpe chos version, can be found in Roesler 2011: 215-217. 
collection of small and important treatises, the Jo bo' $i$ chos chung brgya rtsa ('The 108 Small Treatises of the Master'). The history of the creation of this collection is unclear, but it seems to have existed in the early $12^{\text {th }}$ century if not before. ${ }^{29}$ Apart from a considerable number of works by Atiśa himself, it contains brief Indian didactic works such as letters (lekha), discourses and explanations (kathā and nirdeśa), meditation instructions and the like, and arguably represents a set of concise core texts that were considered essential within Atiśa's tradition. Amongst others, it includes Nāgārjuna's Ratnāvalī and Suhrllekha, which are frequently cited in the Dpe chos and in other Bka'gdams-pa works.

Coming back to Po-to-ba himself, his biographies tell us that he taught the gzhung drug, Atiśa's Bodhipathapradīpa and Satyadvayāvatāra, Nāgārjuna's Ratnāvalī and Suhrllekha, Candragomin's Śișyalekha, Śankarasvāmin's Devatāvimarśastuti and Kamalaśîla's Bhāvanākrama, ${ }^{30}$ which are all contained in the Jo bo'i chos chung as well. The Jo bo'i chos chung also contain the root verses $(k \bar{a} r i k \bar{a})$ of Śāntideva's Śikṣāsamuccaya. In Po-to-ba's tradition of the gzhung pa, Sāntideva's Śikṣāsamuccaya was one of the six "classics" (gzhung drug), and we might therefore presume that this work may have been an important source for Sūtra quotations. Other potential sources are Atiśa's Bodhipathapradīpa-pañjikā and his Mahāsūtrasamuccaya. The former contains numerous quotations and at the same time provides the model for Tibetan lam rim works, and the latter contains ample scriptural material as well. ${ }^{31}$

In the two lam rim works from Po-to-ba's tradition, I have observed an interesting discrepancy: The Dpe chos refers to the Sikșāsamuccaya by name only once, while Dolpa's Be'u bum sngon po with Lha 'Bri-sgang-pa's commentary contain no less than twelve explicit references to the Śikșāsamuccaya. This might indicate that Śāntideva's work was in fact an important resource within Po-to-ba's tradition, even though the Dpe chos refers to the canonical titles of individual works rather than to the Sikșāsamuccaya as its source. I have identified five quotations in the Dpe chos that are also found in the Śikșāsamuccaya, as well as a few references to Sūtra passages (without any verbatim quotations) that are also contained in the Sikșāsamuccaya. On the other hand, it has to be said that the Dpe chos quotes numerous Sutra passages that are not contained in the

${ }^{29}$ The biographies of Atiśa don't mention this collection. However, the A khu dpe tho (no. 11109) lists a Chos chung brgya rtsa'i sa bcad by Gro-lung-pa, which would place the collection in the late $11^{\text {th }}$ or early $12^{\text {th }}$ century, not long after the lifetime of Atiśa. The collection is found in both D and Q, although the Taipei facsimile edition of D has unfortunately excluded it. A comparison of D and Q shows that the sequence of the works in this collection is very similar, although not totally identical in both canon editions. It can furthermore be compared with a list of the Chos chung brgya rtsa contained in Bsod-nams lha'i dbang-po's Bka' gdams chos 'byung nyin mor byed pa'i 'od stong (ed. Gangtok 1977: 373-378 = fol. 104a8-106b2).

${ }^{30}$ For further information see Roesler 2011: $142 \mathrm{f}$.

${ }^{31}$ On scriptural quotations in Atiśa's Mahāsūtrasamuccaya see Mochizuki [2002] and 2004. 
Sikșāsamuccaya, so that it would be wrong to conclude that the Sikșāsamuccaya is the main source for Sūtra quotations in the Dpe chos. All in all it is not unlikely that the Dpe chos draws material from anthologies, but currently I have no hard evidence to prove beyond doubt that specific Dpe chos quotations are taken from the Sikșāsamuccaya, and I am equally unable to assess whether the Dpe chos contains any Sutra quotations cited from the Bodhipathapradīpa-pañjikā or the Mahāsūtrasamuccaya rather than the originals.

Part of this uncertainty is caused by the fact that it is difficult to pin down secondary quotations. The only way to prove that a passage is cited from a secondary source would be to identify variants shared with a secondary work against the primary canonical source. However, due to the inaccuracies of quotations from memory described in the previous section, the wording of the quotation may deviate from its source anyway, and this makes it much harder to compare the material. This becomes obvious when we look at quotations that are shared across several works from the early phyi dar, each of them quoting the same passage with a slightly different wording. Two examples may suffice:

The Dpe chos (no. 6.8.+ in Roesler 2011) contains an anonymous quotation which on further investigation is also found in the Tathāgatajñānamudrāsamādhisūtra. In the Derge blockprint of the $B k a$ ' 'gyur, the stanza runs: ${ }^{32}$

tshogs las bsrings shing rab tu zhi la mos || ri dags lta bur 'jigs shing gnas med rgyu|| nam mkha' rlung bzhin rnyed la mi chags pa $\|$ de 'dra de ni rgyal ba'i chos 'dzin yin ||

"The person who stays away from the crowd and finds pleasure in mental calm, who wanders full of apprehension (or: fearless) without staying anywhere, like the deer, who does not cling to things obtained, like the wind in the sky, this person is a holder of the Buddhist doctrine."

The stanza is found in Atiśa's Mahāsūtrasamuccaya, in Gro-lung-pa's Bstan rim chen mo and in the Dpe chos. These versions run:

Atiśa's Mahāsūtrasamuccaya: ${ }^{33}$ de bzhin gshegs pa'i ye shes kyi phyag rgya'i mdo las kyang | [...]

\footnotetext{
32 D no. 0132, vol. 55, mdo sde da, fol. 241 b.

33 D no. 3966, vol. 37, dbu ma gi, fol. 119a. Ed. Mochizuki 2004: 215.
} 
tshogs las ring zhing rab tu zhi la mos ||

ri dags skrag bzhin gnas pa med par spyod ||

mkha' la rlung bzhin rnyed la chags med pa $\mid$

de 'dra de ni rgyal ba'i chos 'dzin yin $\|$ [...]

Gro-lung-pa's Bstan rim chen mo: $:^{34}$

sangs rgyas kyi ye shes phyag rgyal [!] las kyang $\mid$ [...]

tshogs las bsrings shing rab tu zhi la mos ||

ri dwags lta bur 'jigs shing gnas med rgyu ||

mkha' la rlung bzhin rnyed la mi chags pa

de 'dra de ni rgyal ba'i chos 'dzin yin ||$[\ldots]$

Dpe chos (no. 6.8+ in Roesler 2011):

tshogs las bsring zhing zhi la rab tu mos ||

nam mkha'i rlung bzhin rnyed la ma chags shing ||

ri dwags bzhin du 'jigs med gcig pur rgyu ||

de lta bu ni dam pa'i chos 'dzin yin $\mid$

Line a, bsring : var. lect. srid; line b, nam mkha'i : var. lect. nam mka'; line c, rgyu : var. lect. 'gro

Gro-lung-pa's quotation corresponds verbatim to the stanza in the canon, except for the beginning of the third line. Atiśa's stanza is almost the same, but has the reading ring ('to be far') instead of bsrings in line a, and the third line is similar to Gro-lung-pa's. The Dpe chos deviates more strongly, ${ }^{35}$ but the beginning of its second line corresponds with the original against Gro-lung-pa and Atiśa. Atiśa's and Gro-lung-pa's works quote a slightly longer section than the Dpe chos, and a comparison shows remarkable differences between the two, again demonstrating the high degree of variance in this type of literature.

It is interesting to see that the Tibetans interpreted the second line in different ways. In the original, it is unclear whether the negation (med) refers to both verbs ('jigs and gnas), or only to the second one (gnas). The meaning could thus be "who wanders fearlessly and without staying anywhere, like the deer", or "who is full of apprehension and does not stay anywhere, like the deer". While the Mahāsütrasamuccaya favours the

${ }^{34}$ Accessed through ACIP SL0070N2 and ACIP S0070M2, Bstan rim chen mo chapter 7, fol. 320b.

${ }^{35}$ Here and in other cases it can be observed that the editions of the Dpe chos that are closer to its archetype deviate more strongly from the canonical texts. The redactors of the later blockprint editions of the Dpe chos have slightly adjusted the readings to conform more closely to the canonical mainstream versions. 
second interpretation (ri dwags skrag bzhin gnas pa med par spyod), the Dpe chos prefers the first ( ri dwags bzhin du 'jigs med gcig pur rgyu).

The differences between the quotations both in length and in their phrasing show that there is no direct dependence between any of them. At the same time, the occurrence of this specific quotation in three works from the early phyi dar seems to indicate that the stanza was popular and well-known in these circles. While I am not aware of any evidence that we are dealing with a secondary quotation (unless its secondary source is to be found elsewhere and I have not spotted it), cases such as the present one demonstrate that certain quotations were shared knowledge in Bka'-gdams-pa circles. ${ }^{36}$ The variations again find a natural explanation if we assume that the Bka'-gdams-pa masters were quoting well-known passages from memory. ${ }^{37}$

\section{Conclusion}

The evidence provided here shows that the quotations in works from the early phyi dar give us interesting insights into the way Indian Buddhist works were taught and studied in Tibet during this period (and possibly also in later times). It is possible to discern different types of variations in scriptural quotations:

1. There are rare cases in which the Dpe chos seems to reflect a translation that is different from the canonical mainstream version (such as the two stanzas from the Madhyamakāvatāra in sections 3.1 above.) This should alert us to the fact that it is worth consulting these early Tibetan witnesses from the phyi dar when working on a specific Indian work that existed in several Tibetan translations.

2. Secondly, some deviations seem to be due to the fact that the Bka'-gdams-pa masters are quoting from memory rather than from a manuscript, especially in the case of certain works that were very popular, such as the Lalitavistara and the Bodhicaryāvatāra. This gives us some interesting insights into the way the scriptures were studied and taught and resonates well with the largely oral way of teaching in Po-to-ba's time (i.e., in the $11^{\text {th }}$ century). Regarding the name of his tradition, gzhung pa ('those who transmit the scriptures'), it makes us realise that gzhung does not necessarily refer to a book: gzhung is a 'scripture' in the sense of the work, not a written text. ${ }^{38}$

\footnotetext{
36 In this connection see the discussion on interlanguage in the General Introduction to this volume.

${ }^{37}$ For another similar example see the Gandavyūha quotation in Dpe chos 8.2.3+ (Roesler 2011).

${ }^{38}$ We are dealing with a period of transition from largely oral teaching and learning to a culture of reading and writing. To simplify a little, we can say that Po-to-ba's generation hardly wrote Buddhist literature at all, but their oral instructions were recorded in writing by their students. These students as well as the following generation were the ones who initiated literary composition on a large scale. This goes hand
} 
3. Finally, it seems that the Bka'-gdams-pas share a certain pool of common quotations. The biographies of the individual teachers tell us which works they taught, and we know that Po-to-ba's tradition put particular emphasis on a set of six core texts ( $g$ zhung drug). Apart from these, some texts from the collection Jo bo'i chos chung brgya rtsa seems to have been highly popular. This gives us some impression of the range of literature they used.

Though the variations in the passages quoted make it difficult to prove, it is likely that quotations are not always drawn from individual primary sources, but sometimes from secondary sources such as anthologies that were used for teaching and studying the essentials of Indian Buddhism. The Be'u bum sngon po does in fact refer several times to the Sikșāsamuccaya as its source. The Dpe chos, on the other hand, does not contain any explicit references to such secondary sources because what counts is the scripture quoted, not the resource used. This is in full accordance with the Tibetan understanding of authorship, which in this respect differs from Western conventions: the Tibetan tradition tends to regard the intellectual creator as relevant, not the person who committed the work to writing. Therefore, the author is the person who taught the respective doctrine or text (for example, the Buddha) and a quotation from such a text will mention the title of the respective Sūtra rather than the source (for instance a samuccaya) it may happen to be based on.

It would be desirable to investigate works from this period on a larger scale in order to establish whether the features outlined above are typical for Tibetan Buddhist scholarship during the phyi dar in general, or whether the results vary from work to work. For example, it could turn out that individual authors have different citing habits, or that the accuracy in scriptural quotations depends on the genre of the work involved (such as Tibetan commentaries, independent doctrinal works, didactic poems, Buddhist narrative, letters, and so on). ${ }^{39}$ The collected writings of the Bka'-gdams-pa masters published by the Dpal-brtsegs Institute provide ample material for further investigation.

in hand with a rapid growth of the Bka'-gdams-pa movement and a transition from 'secret' individual instructions (lkog chos) to public teachings to larger numbers of followers (tshogs chos). In this setting, the use of books must have been a convenient method to spread Buddhist thought and to protect it against misunderstandings and corruptions. (See Roesler 2011: 126-131.) On the ambiguous attitudes of Tibetan Buddhists towards books and written Buddhist instructions in general see Schaeffer 2009: 1-7.

${ }^{39}$ Needless to say, these considerations are not entirely specific to Tibetan literature. Other diciplines have been dealing with similar questions for much longer than the relatively young field of Tibetan Studies, and it will be helpful to make use of the research questions and methods they have developed. For example, in his research on quotations from the New Testament in the writings of the Church Fathers, Fee formulates the following questions: "1. The question of copying or citing from memory. [...] 2. The question of [individual] 
Bibliography

Primary sources

A-khu Rin-po-che Shes-rab rgya-mtsho. [A khu dpe tho.] Dpe rgyun dkon pa 'ga' zhig gi tho yig. In Materials for a History of Tibetan Literature, vol. 3. Edited by Lokesh Chandra. (Śata-piṭaka Series 30.) New Delhi 1963.

Atiśa Dīpaṃkaraśrīiñāna. Bodhipathapradīpa. Ein Lehrgedicht des Atiśa (Dīpaṃkaraśrījñāna) in der tibetischen Überlieferung. Herausgegeben von Helmut Eimer. Wiesbaden: Otto Harrassowitz.

----- [Bodhipathapradīpa Engl.] A Lamp for the Path and Commentary of Atīsa. Translated and annotated by Richard Shernburne, S.J. London: George Allen \& Unwin 1987.

----- [Jo bo'i chos chung brgya rtsa.] The Complete works of Atīśa, Śri Dīpampara Jñāna, Jo-bo-rje. The Lamp for the Path and the Commentary, together with the newly translated Twenty-five Key Texts. (Tibetan and English.) Translated and annotated by Richard Sherburne, SJ. Delhi: Aditya Prakashan 2000.

----- Mahāsūtrasamuccaya: see Mochizuki

$B k a$ ' 'gyur and Bstan 'gyur editions used:

D (Derge blockprint edition): The Tibetan Tripitaka. Taipei Edition. Editor-in-Chief A.W. Barber. 72 vols. Taipei 1991.

Q (Beijing blockprint edition): The Tibetan Tripitaka. Peking Edition. Kept in the library of the Otani University, Kyoto. Reprinted under the Supervision of the Otani University, Kyoto. Edited by Daisetz T. Suzuki. 168 vols. Tokyo-Kyoto 1955-1961.

Bsod-nams lha'i dbang-po. Bka' gdams rin po che'i chos 'byung rnam thar nyin mor byed pa' $i$ 'od stong. In Two Histories of the bKa'-gdams-pa Tradition from the Library of Burmiok Athing. [Gangtok, Sikkim 1977.]

Dkar chag 'Phang thang ma [and] Sgra sbyor bam po gnyis pa. Ed. by rTa-rdo. Beijing: Mi rigs dpe mdzod khang 2003.

Dkar chag 'Phang thang ma. Ed. by Eishin Kawagoe. (Tohoku Society for Indo-Tibetan Studies Monograph Series 3.) Tohoku Society for Indo-Tibetan Studies 2005.

citing habits. [...] 3. The character/type of work involved. [...] 4. The number of Bibles used by the Father.“ (Epp \& Fee 1993: 344-45). All of these aspects are equally relevant to the Tibetan context. 
[Dol-pa Shes-rab rgya-mtsho, Be'u bum sngon po with Lha 'Bri-sgang-pa's commentary.] In Gangs can rig brgya'i sgo 'byed lde mig, deb bcu drug pa. Beijing: Mi rigs dpe skrun khang 1991.

Gro-lung-pa, Bstan rim chen mo. Accessed through ACIP, www.asianclassics.org/etext.php

Lalita Vistara: Leben und Lehre des Çâkya-Buddha. Textausgabe mit Varianten-, Metren- und Wörterverzeichnis. Herausgegeben von S. Lefmann. Teil 1: Text. Teil 2: Varianten-, Metren- und Wörterverzeichnis. Halle a.S.: Verlag der Buchhandlung des Waisenhauses 1902-08.

[Po-to-ba Rin-chen-gsal/Lce-sgom Shes-rab rdo-rje.] Dpe chos dang dpe chos rin chen spungs pa. Ed. by Mgon-po dar-rgyas. Beijing: Mi rigs dpe skrun khang 1991. [For further editions, blockprints and manuscripts see Roesler 2011, chapter 7.]

[Sgra sbyor bam po gnyis pa.] Materials for Tibetan-Mongolian Dictionaries, Vol. 2: A Critical Edition of the Sgra sbyor bam po gnyis pa: An Old and Basic Commentary on the Mahāvyutpatti. Ed. by Mie Ishikawa. (Studia Tibetica no. 18.) Tokyo: The Toyo Bunko 1990.

Secondary sources

Dreyfuss, Georges B.J. 2003. The Sound of Two Hands Clapping: The Education of a Tibetan Buddhist Monk. Berkeley etc.: University of California Press.

Eimer, Helmut see Atiśa, Bodhipathapradīpa

Epp, Edon Jay and Gordon D. Fee 1993. Studies in the Theory and Method of New Testament Textual Criticism. (Studies and Documents 45.) Grand Rapids, Michigan: William B. Eerdmans Publishing Company.

Halkias, Georgios 2004. "Tibetan Buddhism Registered: a Catalogue from the Imperial Court of 'Phang Thang." The Eastern Buddhist, New Series vol. XXXVI, nos 1\&2: 46-105.

Jackson, David 1996. "The bsTan rim ("Stages of the Doctrine") and Similar Graded Expositions of the Bodhisattva's Path." In Tibetan Literature: Studies in Genre. Ed. by José Ignacio Cabezón and Roger R. Jackson. Ithaca, New York: Snow Lion Publications: 229-243.

van der Kuijp, Leonard 2001. "On the Fifteenth Century Lho rong chos 'byung by Rta tshag Tshe dbang rgyal and Its Importance for Tibetan Political and Religious History." Lungta 14: 57-76. 
Lalou, Marcelle 1953. "Les textes bouddhiques au temps de Khri-sron-lde-bcan.” Journal Asiatique 1953: 313-353.

Langelaar, Reinier J. Quoting Sūtra Scond-Hand: Sūtra, Śāstra \& Other Sources in Tsongkhapa’s Lamrim Chenmo. B.A. thesis, Leiden University, 2011.

Lefmann, Salomon 1902-1908 see Lalita Vistara

Mochizuki, Kaie [2002]. A Study of the Mahāsūtrasamuccaya of Dīpaṃkaraśrījñāna. A Report of Grant-in-Aid for Encouragement of Young Scientists. Minobu: Minobusan University.

2004. A Study of the Mahāsūtrasamuccaya of Dīpaṃkaraśrījñāna II: Tibetan Text. Minobu: Minobusan University.

Roesler, Ulrike 2011. Frühe Quellen zum buddhistischen Stufenweg in Tibet: Indische und tibetische Traditionen im dPe chos des Po-to-ba Rin-chen-gsal. (Monographien zur indischen Archäologie, Kunst und Philologie 20.) Wiesbaden: Reichert Verlag.

Roesler, Ulrike and Hans-Ulrich 2004. Kadampa Sites of Phempo: A Guide to Some Early Buddhist Monasteries in Central Tibet. (Bauddha Books 2.) Kathmandu: Vajra Publications.

Schaeffer, Kurtis R. 2009. The Culture of the Book in Tibet. New York; Chichester: Columbia University Press.

Scherrer-Schaub, Cristina 2002. "Enacting Words: A Diplomatic Analysis of the Imperial Decrees (bkas bcad) and their Application in the sGra sbyor bam po gñis pa Tradition." Journal of the International Association for Buddhist Studies 25, 1-2: 263-340.

2009. “Copier, interpreter, transformer, represénter, ou Des modes de la diffusion des Écritures et de l'écrit dans le bouddhisme indien." In Écrire et transmettre en Inde classique. Ed. by Gérard Colas et Gerdi Gerschheimer. (Études thématiques 23.) Paris: École française d'Extrême-Orient: 151-172.

Simonsson, Niels 1957. Indo-tibetische Studien. Die Methoden der tibetischen Übersetzer, untersucht im Hinblick auf die Bedeutung ihrer Übersetzungen für die Sanskritphilologie I. Uppsala: Almqvist \& Wiksells Boktrycheri AB.

Skilling, Peter 1997. "From $b K a$ ' bstan bcos to $b K a$ ' 'gyur and bsTan 'gyur." In Transmission of the Tibetan Canon: Papers Presented at a Panel of the $7^{\text {th }}$ Seminar of the International Association for Tibetan Studies, Graz 1995. Ed. by Helmut Eimer. (Österreichische Akademie der Wissenschaften. Philosophisch-historische Klasse, 
Denkschriften 257). Wien: Verlag der Österreichischen Akademie der Wissenschaften: $87-111$.

Sørensen, Per K. 1999. "The Prolific Ascetic 1Ce-sgom Śes-rab rdo-rje alias 1Ce-sgom źig-po: Allusive, but Elusive." Journal of the Nepal Research Centre XI: 175200 .

Steinkellner, Ernst 1995. Sudhana's Miraculous Journey in the Temple of Tha pho. The inscriptional text of the Gandavyūhasūtra edited with introductory remarks. (Serie Orientale Roma LXXVI.) Roma: IsMEO.

Tauscher, Helmut 1981. Candrakīrti: Madhyamakāvatāra und Madhyamakāvatārabhāsyam (Kapitel VI, Vers 166-226) übersetzt und kommentiert. (Studien zur Tibetologie und Buddhismuskunde, Heft 5.) Wien: Verlag der Österreichischen Akademie der Wissenschaften.

1989. Verse-index of Candrakīrti's Madhyamakāvatāra (Tibetan versions).

(Wiener Studien zur Tibetologie und Buddhismuskunde 22.) Wien: Arbeitskreis für tibetische und buddhistische Studien.

Tshul-khrims [Bshes-gnyen Tshul-khrims rgyal-mtshan] 2001. Lha sa'i dgon tho rin chen spungs rgyan. Lhasa: Bod ljongs mi dmangs dpe skrun khang.

Wedemeyer, Christian 2006. "Tantalising Traces of the Labours of the Lotsāwas:

Alternative Translations of Sanskrit Sources in the Writings of Rje Tsong kha pa.”

In Tibetan Buddhist Literature and Praxis: Studies in its Formative Period, 9001400. PIATS 2003, Tibetan studies: Proceedings of the Tenth Seminar of the International Association for Tibetan Studies, Oxford, 2003. Ed. by Ronald M. Davidson and Christian Wedemeyer. (Brill's Tibetan Studies Library 10,4.) Leiden; Boston: Brill: 149-182. 